\title{
Presence of fluoroquinolones and sulfonamides in urban sewage sludge and their degradation as a result of composting
}

\author{
${ }^{1}$ M. Lillenberg; ${ }^{2}$ S. Yurchenko; ${ }^{2}$ K. Kipper; ${ }^{2}$ K. Herodes; ${ }^{2}$ V. Pihl; ${ }^{3}$ R. Lõhmus; \\ ${ }^{4}$ M. Ivask; ${ }^{4}$ A. Kuu; ${ }^{4}$ S. Kutti; ${ }^{4}$ S. V. Litvin; ${ }^{4}$ L. Nei \\ ${ }^{1}$ Department of Food Science and Hygiene, Estonian University of Life Sciences, Kreutzwaldi 58A, 51014 \\ Tartu, Estonia \\ ${ }^{2}$ Institute of Chemistry, University of Tartu, Jakobi 2, 51014 Tartu, Estonia \\ ${ }^{3}$ Institute of Physics, University of Tartu, Riia 142, 51014 Tartu, Estonia \\ ${ }^{4}$ Department of Environmental Protection, Tartu College of Tallinn University of Technology, Puiestee 78, 51008 \\ Tartu, Estonia
}

Received 5 October पए—; $\quad$ revised 5 February 2010; accepted 25 February 2010 avaiable online 1 March 2010

\begin{abstract}
The concentrations of some widely used pharmaceuticals, namely fluoroquinolones (ciprofloxacin $\mathrm{C}_{17} \mathrm{H}_{18} \mathrm{FN}_{3} \mathrm{O}_{3}$, norfloxacin $\mathrm{C}_{16} \mathrm{H}_{18} \mathrm{FN}_{3} \mathrm{O}_{3}$ and ofloxacin $\mathrm{C}_{18} \mathrm{H}_{20} \mathrm{FN}_{3} \mathrm{O}_{4}$ ) and sulfonamides (sulfadimethoxine $\mathrm{C}_{12} \mathrm{H}_{14} \mathrm{~N}_{4} \mathrm{O}_{4} \mathrm{~S}$ and sulfamethoxazole $\mathrm{C}_{10} \mathrm{H}_{11} \mathrm{~N}_{3} \mathrm{O}_{3} \mathrm{~S}$ ) were determined in urban sewage sludge utilized for making compost. The levels of degradation of these pharmaceuticals resulting from sludge treatment were assessed. The concentrations of the studied pharmaceuticals sufficiently varied both in sewage sludge and in compost and due to this phenomenon the possible danger resulting from the presence of pharmaceuticals in sewage sludge, used for composting, can not be ignored. The concentrations of the studied pharmaceuticals were lower in compost, if compared to the relevant concentrations in sewage sludge. The highest pharmaceutical concentration in sewage sludge - $426 \mu \mathrm{g} / \mathrm{kg}-\mathrm{was}$ detected in the case of ciprofloxacin. The highest concentrations present in compost were $22 \mu \mathrm{g} / \mathrm{kg}$ of norfloxacin and $20 \mu \mathrm{g} / \mathrm{kg}$ of ciprofloxacin. Results show that before using the sewage sludge for making compost or before using the compost a fertilizer for food plants, they should be carefully tested against the content of commonly used pharmaceuticals.
\end{abstract}

Keywords: Ciprofloxacin; Norfloxacin; Ofloxacin; Pharmaceuticals; Soil pollution; Sulfadimethoxine; Sulfamethoxazole

\section{INTRODUCTION}

Due to rapid increase in urban population the amount of sewage sludge has increased dramatically in the past 20 y. Environmental pollution caused by sewage sludge has become a serious social problem, which hinders urban development. It is of utmost importance to find ways of effective re-usage of this waste and reduce its impact on the environment (Lu et al., 2009). Sewage sludge can be used to generate energy which could be saved on the fossil fuels conventionally used as a source of energy (Babel et al., 2009). Incineration is costly and contributes to air pollution and landfill space is becoming scare (Mahzuz et al., 2009). The use of sewage sludge in agriculture is one of the major causes of environmental pollution (Nouri et al., 2008). Sewage sludge is the residue from the treatment of domestic and industrial wastewater. It contains useful organic matter and nutrients for plants (Kaonga et al., 2010). The contents of nitrogen, phosphorus and organic matter are up to 10 times higher in sewage sludge and its compost, if compared to common Estonian agricultural soils. Still, its usage as a fertilizer is limited due to a large number of toxic pollutants found in this matter. As the amount of sewage sludge is growing rapidly all over the world, the problems involving sewage sludge safety, treatment and usage are a global concern. Composting or aerobic biological treatment of organic wastes is an ancestral way to reduce wastes and to reuse organic matter. Among the range of existing organic wastes, sewage sludge composting enables the production of a quality product that may be used as a soil conditioner or as an organic fertilizer (Tremier et al., 2005; Suthar and Sing, 2008) since its organic matter content can vary from 50 $\%$ to $70 \%$ of the total solids content (Banegas et al., 2007). The quality of compost depends on its 
environmental compatibility and the correspondence to market necessities. These features involve the absence of toxic inorganic and organic compounds, which may enter the food chain through the plant uptake (Lazzari et al., 2000). Pharmaceuticals are often present in sewage sludge. Their quantities rise from year to year. In spite of the fact that very low drug levels in the environment can have undesirable ecological and health effects, until now the problems related to the presence of pharmaceuticals in sewage sludge and its compost have received little attention (Carballa et al., 2007). Over the past decade, the scientific community has become increasingly interested in the impact of pharmaceutical contaminants on the environment and human health. A large proportion of pharmaceuticals is introduced into the environment via sewage treatment plants. A number of papers present the studies involving the occurrence and removal of pharmaceutical compounds in sewage treatment systems (Jones et al., 2007; Matamoros et al., 2009; Radjenović et al., 2009). The presence and possible accumulation of these substances in sewage sludge are acknowledged. Current national and international regulations governing the application of sewage sludge ignore the presence and fate of pharmaceuticals. It has been shown that the degradation of pharmaceuticals may take place during bio-solid composting (Buyuksonmez and Sekeroglu, 2005). Potentials of phototrophic bacteria in treating pharmaceutical wastewater are shown in Madukasi et al., (2010). No systematic work concerning biodegradation of pharmaceuticals during sewage sludge composting has been published. Remarkable amounts of pharmaceuticals enter the terrestrial environment by fertilizing with sewage sludge compost or manure (Halling-Sørensen et al., 1998). No trigger values exist for their residues in sewage compost in the European Union. The content of drug residues should not exceed $100 \mu \mathrm{g} / \mathrm{kg}$ in manure and $10 \mu \mathrm{g} / \mathrm{kg}$ in soil (EMEA/CVMP/055/96, 1996). Little information is available on degradation of pharmaceuticals in the environment. It has been shown that antibacterial drugs can bind strongly to solid particles, which could be an additional reason for their slow degradation (Marengo et al., 1997; Carmosini and Lee, 2008). Their residues with long persistence may be harmful for aquatic and terrestrial organisms; they may accumulate in food plants and finally reach human or animal food(Lillenberg et al., 2003). Plants unlike animals have no excretion. As a result concentrations of drug residues in food plants may exceed the maximum residue limits (MRL) for meat and milk. Antibacterial drugs consumed in very small amounts with everyday food may generate the strains of resistant bacteria in human and animal organism, provoke allergy and affect the liver (Lillenberg et al., 2003). The sewage sludge and sewage sludge compost from sewage treatment plants of the two Estonian largest cities - Tallinn and Tartu - were analyzed. Also, three random sewage samples from Tartu were analyzed with the aim of estimating the level of the residues of the studied pharmaceuticals. The selection of pharmaceuticals was made considering their stability in soil during 6-12 months period(Golet et al., 2002a) and their potential ability to accumulate into plants (Migliore et al., 1995; Migliore et al., 1996; Lillenberg et al., 2003). These pharmaceuticals include fluoroquinolones and sulfonamides: ciprofloxacin (CIP), norfloxacin (NOR), ofloxacin (OFL), sulfadimethoxine (SDM) and sulfamethoxazole (SMX). Fluoroquinolones and sulfonamides represent the most commonly used families of antibiotics (Pérez et al., 2005; Picó and Andreu, 2007). CIP is the most widely prescribed fluoroquinolone in the world, followed by OFL. That was the reason why we carried out some experiments with the aim of studying the uptake of CIP by lettuce. NOR, an oral broad-spectrum antibacterial agent is very common in Europe (Picó and Andreu, 2007). SDM is indicated for the treatment of a wide range of respiratory, genitourinary tract, enteric, and soft tissue infections. SMX is an anti-bacterial sulfonamide that inhibits the synthesis of dihydrofolic acid, a compound that bacteria must be able to make to survive. As one of the most consumed sulfonamides in human medicine, this pharmaceutical has been reported most frequently and is usually considered ecologically harmful (García-Galán et al., 2009). In the present study SDM and SMX were chosen as target antibiotics because of their widespread use (Isidori et al., 2005; De Liguoro et al., 2007). The current study was completed in 2007 and 2008 in Tartu, Estonia.

\section{MATERIALS AND METHODS}

The sewage sludge in Tartu is treated by composting - mixing with tree bark (volume ratio 2:3). The methane fermentation and mixing with peat (volume ratio 4:3) are used in Tallinn. The samples were taken in 20072008 from anaerobically digested sludge (before mixing with peat) in Tallinn and from untreated sludge (before composting) in Tartu, three samples in a month from both cities during a year. The compost samples were taken from stacks with different ages: 2, 6 and 12 months, 6 samples from different parts of stack in Tallinn and Tartu. Three stacks in both cities were piled up two 
months before sampling. Two stacks in each city were made six months before taking samples; and one stack in Tartu and one in Tallinn had been stored for twelve months. The total amount of samples was 144, half of them were obtained from Tartu and half from Tallinn. Approximately $200 \mathrm{~g}$ of sludge (content of dry matter $28 \%$ in Tallinn and $25 \%$ in Tartu) or compost was placed into $500 \mathrm{~mL}$ glass jar, mixed thoroughly and covered hermetically with lid. Before analyses, the samples were stored in refrigerator at temperature $+4{ }^{\circ} \mathrm{C}$ in the dark. Lettuce was grown in plastic pots (Fig. 1), filled with soil amended with CIP. The initial concentrations of CIP in soil were: 500, 200, 50 and $10 \mathrm{mg} / \mathrm{kg}$. Lettuce was harvested on the 42 nd day after seeding. The concentration of CIP was determined using the agar diffusion methodology described in Lillenberg et al. (2003). Dried, grounded and weighted plant material was placed on an agar medium inoculated with antibioticsensitive bacterium Bacillus subtilis. The pharmaceutical diffused from plant material to the agar medium and inhibited the bacterial growth around the studied matter. The measured diameter of the inhibition circle allowed to determine the concentrations of the studied pharmaceutical in plant samples. A simple calibration procedure, using spiked plant matter, was used for generating calibration plots. The uncertainty of the drug concentration measurement was $\pm 10 \%$. This methodology was chosen due to its availability, inexpensiveness and rapidness, if compared to the routinely used chromatographic work. Pharmaceuticals used for standardization were purchased from Riedelde-Haën. Purity: CIP - 99.8 \%, NOR - 99.9\%, OFL - 99.3 \%, SDM - 99.4 \%, SMX - $99.9 \%$. Acetonitrile and methanol were obtained from J.T.Baker, phosphoric acid

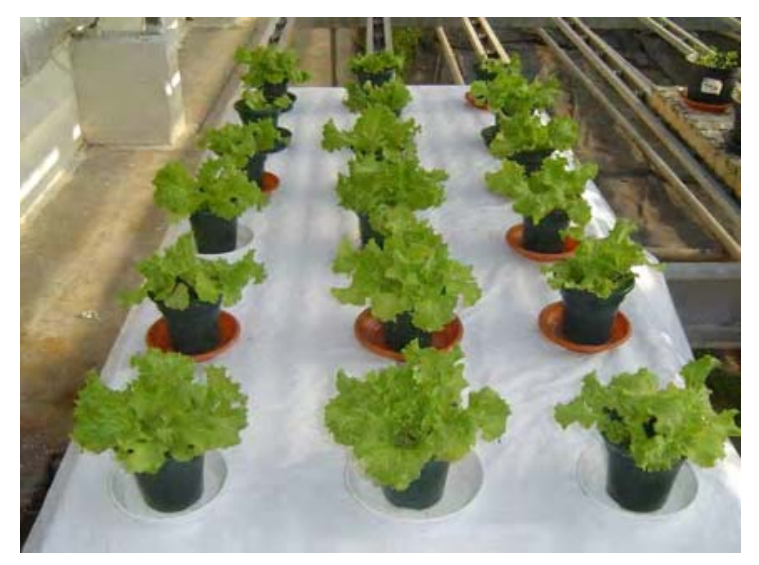

Fig. 1: Lettuce, $40^{\text {th. }}$ day after seeding from Lachema, citric acid monohydrate from Fisher Scientific, formic acid from Riedel-de-Haën, ammonium acetate from Fluka Chemie AG. All solvents were of reagent grade or higher quality. The following equipment was used for analysis: in-house built pressurized liquid extraction (PLE) system, hydrophiliclipophilic balanced (HLB) solid phase extraction (SPE) cartridges (Oasis HLB $(60 \mu \mathrm{m}), 500 \mathrm{mg} / 6 \mathrm{~mL}$ ) by Waters (Milford, MA, USA) and Agilent Series 1100 LC-MSD Trap XCT (Santa-Clara, CA, USA) with an analytical column Phenomenex Synergi Hydro-RP (250 mm x 4.6 $\mathrm{mm}, 4 \mathrm{um})$. Pharmaceuticals were extracted by PLE method, the extracts cleaned up by SPE method (Lillenberg et al., 2009). The SPE step was necessary for removal of other organic contaminants that suppressed ionization and thus disabled the detection of minor amounts of substance. HPLC-MS/MS (liquid chromatography coupled with tandem mass spectrometry) was used for analysis (Lillenberg et al., 2009). Relative standard deviation (RSD) of the determinations was within $2 \%$.

\section{RESULTS AND DISCUSSION}

In most of the studied sewage sludge and compost samples the concentrations of pharmaceuticals were clearly extremely low, but (surprisingly) in some sludge samples the content of pharmaceuticals still exceeded 100 $\mu \mathrm{g} / \mathrm{kg}$, and in some sewage compost samples the drug concentrations were above $10 \mu \mathrm{g} / \mathrm{kg}$. The relevant concentration ranges of the detected pharmaceuticals for the whole set of studied sewage sludge and compost samples are presented in Table 1. Remarkable concentration variations can be followed due to the heterogeneity of the studied matter. Our results concerning the content of the studied residues of pharmaceuticals in Tartu sewage and some data concerning the occurrence of these compounds in U.S. streams have been included for comparison into Table 1. Interestingly CIP and OFL were not present in the randomly taken sewage samples in Tartu. In spite of this in some sludge and compost samples their presence was obvious, reaching to $111 \mu \mathrm{g} / \mathrm{kg}$ in the case of CIP and 39 $\mu \mathrm{g} / \mathrm{kg}$ in the case of OFL. The large variability of the concentrations of pharmaceuticals in sewage and sewage sludge was apparent. As a result of this the concentration of pharmaceuticals varies noticeably within the same compost stack. An example of this phenomenon is presented in Table 2. The results presented in Table 2 show that the content of fluoroquinolones differs up to 1.8 times within the same stack. The determined 
concentrations of sulfonamides were much lower, if compared to the concentrations of fluoroquinolones. Surprisingly, the concentration of SDM was under the detection limit $(0.01 \mu \mathrm{g} / \mathrm{kg})$. For another Tartu compost stack the SDM concentrations were in the range 0.1 - 0.4 $\mu \mathrm{g} / \mathrm{kg}$. The concentrations of the studied pharmaceuticals - fluoroquinolones and sulfonamides sufficiently varied both in sewage sludge and in compost. Therefore the possible danger resulting from the content of pharmaceuticals in sewage sludge can not be ignored. The concentrations of the studied pharmaceuticals in compost were up to one order of magnitude lower, if compared to the relevant concentrations in sewage sludge. Partly this effect is caused by adding peat or tree bark to sewage sludge. Still, the main reason of the decrease in pharmaceutical concentrations during composting is the applied sludge treatment technology. The safest way to exclude exposing plants to pharmaceuticals in to ensure that these substances are adequately degraded before sewage sludge compost is applied onto arable land. The decomposition of pharmaceuticals was faster in the case of Tallinn composting technology. Interestingly, SDM was present in most sludge and 2 month stored compost samples, although this antimicrobial was not marketed in the years 2007 and 2008 in Estonia. It is possible that 3 old supplies were put to use or small amounts of this chemical were imported from other countries. It is known that fluoroquinolones are eliminated in conventional sewage treatment by $90 \%$ with sorption to sewage sludge being the main process responsible (Golet et al., 2002b, 2003). For sulfonamides, sorption to sewage sludge has been found to be of minor importance (Göbel et al., 2005, 2007). As the highest concentrations were detected for CIP, the results of the experiments carried out with the aim of studying the uptake of CIP by lettuce (and described in detail in Lillenberg et al., 2003) are shown in a generalized form in Table 3 . In the case of relatively low CIP concentrations in soil (less than $50 \mathrm{mg} / \mathrm{kg}$ ) a remarkable accumulation of this pharmaceutical by lettuce was followed. This clearly shows that before using the sewage sludge compost as a fertilizer for crops it should be tested against the residues of commonly used pharmaceuticals, and the presence and breakdown of a variety of other compounds of concern needs to be studied under realistic conditions, leading to field-scale trials. Further investigations on the on the mobility and bioavailability, persistence, degradation pathways and kinetics of pharmaceuticals present in sewage, sewage sludge, compost, soils and plants are needed. Other bulking agents, as for example sawdust (Banegas et al., 2007) can be considered for use with sewage sludge.

Table 1: Pharmaceuticals in sewage sludge and compost

\begin{tabular}{|c|c|c|c|c|c|c|}
\hline \multirow[b]{2}{*}{ Place } & \multirow[b]{2}{*}{ Sample } & \multicolumn{5}{|c|}{ Concentrations of pharmaceuticals, $\mu \mathrm{g} / \mathrm{kg}$} \\
\hline & & NOR & CIP & OFL & SMX & SDM \\
\hline \multirow[t]{3}{*}{ Tartu } & sewage* & 0.07 & 0.00 & 0.00 & 0.42 & 0.01 \\
\hline & sludge & $0.0-110$ & 2.6-111 & $0.5-39$ & $0.0-2.8$ & $0.0-7.9$ \\
\hline & compost & $0.0-22$ & $0.0-20$ & $0.0-3.2$ & $0.0-0.9$ & $0.0-4.2$ \\
\hline \multirow[t]{2}{*}{ Tallinn } & sludge & $0.0-162$ & $0.0-426$ & $0.0-38$ & $0.0-6.0$ & $0.0-20$ \\
\hline & compost & $0.0-5.4$ & $0.0-7.1$ & $0.0-0.5$ & $0.0-0.3$ & $0.0-0.2$ \\
\hline USA & streams** & 0.12 & 0.49 & $0.03^{1}$ & 0.15 & 0.06 \\
\hline
\end{tabular}

*3 sewage samples were taken randomly: average concentrations of pharmaceuticals

**139 stream sites in on areas considered susceptible to contamination from wastewater, median concentrations are presented (Kolpin et al., 2002; except ${ }^{1}$ - detected in Seine River: Tamtam et al., 2008)

Table 2: The concentrations of pharmaceuticals in compost samples obtained from different parts of the same compost stack in Tartu

\begin{tabular}{|c|c|c|c|c|c|}
\hline \multirow[b]{2}{*}{ Sample No. } & \multicolumn{4}{|c|}{ Concentrations of pharmaceuticals ( $\mu \mathrm{g} / \mathrm{kg})$} & \multirow[b]{2}{*}{ SDM } \\
\hline & NOR & CIP & OFL & SMX & \\
\hline 1 & 12.0 & 13.1 & 2.8 & 0.6 & 0.0 \\
\hline 2 & 11.1 & 11.0 & 2.6 & 0.2 & 0.0 \\
\hline 4 & 7.7 & 9.1 & 1.8 & 0.4 & 0.0 \\
\hline 5 & 10.8 & 10.6 & 2.3 & 0.0 & 0.0 \\
\hline 6 & 6.6 & 7.7 & 1.6 & 0.2 & 0.0 \\
\hline
\end{tabular}

Table 3: Ciprofloxacin uptake by lettuce

\begin{tabular}{llll}
\hline Initial CIP concentration in soil, $\mathrm{mg} / \mathrm{kg}$ & 500 & 200 & 50 \\
\hline CIP in lettuce, $42^{\text {nd. }}$ day after seeding, $\mathrm{mg} / \mathrm{kg}$ & 223 & 163 & 58 \\
\hline
\end{tabular}




\section{CONCLUSION}

This study showed that the concentrations of the studied fluoroquinolones (ciprofloxacin, norfloxacin and ofloxacin) and sulfonamides (sulfadimethoxine and sulfamethoxazole) - sufficiently varied both in sewage sludge and in compost. The concentrations of pharmaceutical residues in compost were significantly lower, if compared to the relevant concentrations in sewage sludge. The degradation of pharmaceutical residues was more efficient in Tallinn probably due to anaerobical sludge digestion (compost was made by mixing the treated sewage sludge with peat), if compared to the results obtained in Tartu (raw sewage sludge was mixed with tree bark). It is concluded that before using the sewage sludge compost as a fertilizer it should be carefully tested against the content of different pharmaceuticals. The content of pharmaceuticals in the compost made from sewage sludge may easily lead to the elevated concentrations in food plants, if the compost is used as a fertilizer. This work shows that studies of the sewage sludge used for making compost and the development of novel sewage sludge treatment technologies are needed with the aim of solving environmental problems related to sewage sludge exploitation.

\section{ACKNOWLEDGEMENTS}

This work was funded by Estonian Environmental Investment Centre, Estonian Science Foundation (different grants) and Estonian research target project SF 0180058s07.

\section{REFERENCES}

Babel, S.; Sae-Tang, J.; Pecharaply, A., (2009). Anaerobic codigestion of sewage and brewery sludge for biogas production and land application. Int. J. Environ. Sci. Tech., 6 (1), 131140 (10 pages).

Banegas, V.; Moreno, J. L.; Moreno, J. I.; García, C.; León, G.; Hernández, T., (2007). Composting anaerobic and aerobic sewage sludges using two proportions of sawdust. Waste Manage., 27 (10), 1317-1327 (11 pages).

Buyuksonmez, F.; Sekeroglu, S., (2005). Presence of pharmaceuticals and personal care products (PPCPs) in biosolids and their degradation during composting. J. Resour. Sci. Tech., 2 (1), 31-40 (10 pages).

Carballa, M.; Omil, F.; Ternes, T.; Lema, M. J., (2007). Fate of pharmaceutical and personal care products (PPCPs) during anaerobic digestion of sewage sludge. Water Resour., 41(10), 2139-2150 (12 pages).

Carmosini, N.; Lee, L. S., (2008). Sorption and degradation of selected pharmaceuticals in soil and manure, in: Aga, D. S. (Ed.), Fate of pharmaceuticals in the environment and in water treatment systems. CRC Press, Boca Raton, London, New York.

De Liguoro, M.; Poltronieri, C.; Capolongo, F; Montesissa, C., (2007). Use of sulfadimethoxine in intensive calf farming:
Evaluation of transfer to stable manure and soil. Chemosphere, 68 (4), 671-676 (6 pages).

EMEA/CVMP/055/96, (1996). Commitee for Veterinary Medicinal Poducts. Note for guidance: environmental risk assessment for veterinary medicinal products other than GMOcontaining and immunological products.

García-Galán, M. J.; Díaz-Cruz, M. S.; Barceló, D., (2009). Combining chemical analysis and ecotoxicity to determine environmental exposure and to assess risk from sulfonamides. Trends Anal. Chem., 28 (6), 804-819 (16 pages).

Göbel, A.; McArdell, C. S.; Joss, A.; Siegrist, H.; Giger, W. (2007). Fate of sulfonamides, macrolides, and trimethoprim in different wastewater treatment technologies. Sci. Total Environ. 372 (2-3), 361-371 (11 pages).

Göbel, A.; Thomsen, A.; McArdell, C. S.; Joss, A.; Giger, W., (2005). Occurrence and Sorption Behavior of Sulfonamides, Macrolides, and Trimethoprim in Activated Sludge Treatment. Swiss Federal Institute for Environmental Science and Technology (EAWAG), CH-8600 Dbendorf, Switzerland. Environ. Sci. Tech., 39 (11), 3981-3989 (9 pages).

Golet, E. M.; Alder, A. C.; Giger, W., (2002a). Environmental exposure and risk assessment of fluoroquinolone antibacterial agents in wastewater and river water of the Glatt valley watershed, Switzerland. Environ. Sci. Tech., 36 (17), 36453651 (7 pages).

Golet, E. M.; Strehler, A.; Alder, A. C.; Giger, W., (2002b). Determination of fluoroquinolone antibacterial agents in sewage sludge and sludge-treated soil using accelerated solvent extraction followed by solid-phase extraction. Anal. Chem., 74 (21) 5455-5462 (8 pages).

Golet, E. M.; Xifra, I.; Siegrist, H.; Alder, A. C.; Giger, W., (2003). Environmental exposure assessment of fluoroquinolone antibacterial agents from sewage to soil. Environ. Sci. Tech., 37 (15), 3243-3249 (7 pages).

Halling-Sørensen, B.; Nielsen, S. N.; Lanzky, P. F.; Ingerslev, F.; Lützhøft, H. C. H.; Jørgensen, S. E., (1998). Occurrence, fate and effects of pharmaceutical substances in the environment - A review. Chemosphere, 36 (2), 357-394 (38 pages).

Isidori, M.; Lavorgna, M.; Nardelli, A., (2005). Toxic and genotoxic evaluation of six antibiotics on non-target organisms. Sci. Total Environ., 346 (1-3), 87-98 (12 pages).

Jones O. A. H.; Voulvoulis N.; Lester J. N., (2007). The occurrence and removal of selected pharmaceutical compounds in a sewage treatment works utilising activated sludge treatment. Environ. Pollut., 145 (3), 738-744 (7 pages).

Kaonga, C. C.; Kumwenda, J.; Mapoma, H. T., (2010). Accumulation of lead, cadmium, manganese, copper and zinc by sludge worms; Tubifex tubifex in sewage sludge. Int. J. Environ. Sci. Tech., 7 (1), 119-126 (8 pages).

Kolpin, D. W.; Furlong, E. T.; Meyer, M. T.; Thurman, E. M.; Zaugg, S. D.; Barber, L. B.; Buxton H. T., (2002). Pharmaceuticals, hormones, and other organic wastewater contaminants in U.S. streams, 1999-2000: a national reconnaissance. Environ. Sci. Tech., 36 (6), 1202-1211 (10 pages).

Lazzari, L.; Sperni, L.; Bertin, P.; Pavoni, B., (2000). Correlation between inorganic (heavy metals) and organic (PCBs and PAHs) micropollutant concentrations during sewage sludge composting processes. Chemosphere, 41 (3), 427-435 (9 pages). 
Lillenberg, M.; Roasto, M.; Püssa, T., (2003). Drug residues in environment. Estimation of fluoroquinolones in soil and food plants. J. Agr. Sci., 14 (1), 13-26 (14 pages).

Lillenberg, M.; Yurchenko, S.; Kipper, K.; Herodes, K.; Pihl, V.; Sepp, K.; Lõhmus, R; Nei, L., (2009). Simultaneous determination of fluoroquinolones, sulfonamides and tetracyclines in sewage sludge by pressurized liquid chromatography and electrospray ionization-mass spectrometry. J. Chromatographia. A, 1216 (32), 5949-5954 (6 pages).

Lu, Y. J.; Wu, X. W.; Guo, J. F., (2009). Characteristics of municipal solid waste and sewage sludge co-composting. Waste Manage., 29 (3), 1152-1157 (6 pages).

Madukasi, E. I.; Dai, X.; He, C.; Zhou, J., (2010). Potentials of phototrophic bacteria in treating pharmaceutical wastewater. Int. J. Environ. Sci. Tech., 7 (1), 165-174 (10 pages).

Mahzuz, H. M. A.; Alam, R.; Alam, N. M.; Basak, R.; Islam, S. M., (2009). Use of arsenic contaminated sludge in making ornamental bricks. Int. J. Environ. Sci. Tech., 6 (2), 291-298 (8 pages).

Marengo, J. R.; Kok, R. A.; O’Brien, G. K.; Velagaletti, R. R.; Stamm, J. L., (1997). Aerobic biodegradation of (C-14)sarafloxacin hydrochloride in soil. Environ. Toxicol. Chem., 16 (3), 462-471 (10 pages).

Matamoros V.; Hijosa M.; Bayona J. M., (2009). Assessment of the pharmaceutical active compounds removal in wastewater treatment systems at enantiomeric level. Ibuprofen and naproxen. Chemosphere, 75 (2), 200-205 (6 pages).

Migliore, L.; Brambilla, G.; Casoria, P.; Civitareale, C.; Cozzolino, S.; Gaudio, L., (1996). Effect of sulphadimethoxine contamination on barley (Hordeum distichum L, Poaceae, Liliopsida). Agricult. Ecosyst. Environm., 60 (2-3), 121128 (8 pages).

Migliore, L.; Brambilla, G.; Cozzolino S.; Gaudio, L., (1995).
Effect on plants of sulfadimethoxine used in intensive farming (panicum-miliaceum, pisum-sativum and zea-mays). Agricult. Ecosyst. Environ., 52 (2-3), 103-110 (8 pages).

Nouri, J.; Mahvi, A. H.; Jahed, G. R.; Babaei, A. A., (2008). Regional distribution pattern of groundwater heavy metals resulting from agricultural activities. Environ. Geo., 55 (6), 1337-1343 (7 pages).

Pérez, S.; Eichhorn, P.; Aga D. S., (2005). Evaluating the biodegradability of sulfamethazine, sulfamethoxazole, sulfathiazole and trimethoprim at different stages of sewage treatment. Environ. Toxicol. Chem., 24 (6), 1361-1367 (7 pages).

Picó, Y.; Andreu, V., (2007). Fluoroquinolones in soil - risks and challanges. Anal. Bioanal. Chem., 387, 1287-1299 (13 pages).

Radjenovic J.; Petrović M.; Barceló D., (2009). Fate and distribution of pharmaceuticals in wastewater and sewage sludge of the conventional activated sludge (CAS) and advanced membrane bioreactor (MBR) treatment. Water Res., 43 (3), 831-841 (11 pages).

Suthar, S.; Singh, S., (2008). Vermicomposting of domestic waste by using two epigeic earthworms (Perionyx excavatus and Perionyx sansibaricus). Int. J. Environ. Sci. Tech., 5 (1), 99106 (8 pages).

Tamtam, F.; Mercier, F.; Le Bot, B.; Eurin, J., Dinh, Q. T.; Clément, M.; Chevreuil, M., (2008). Occurrence and fate of antibiotics in the Seine River in various hydrological conditions. Sci. Total Environ., 393 (1), 84-95 (12 pages).

Tremier, A.; de Guardia, A.; Massiani, C.; Paul, E.; Martel, J. L., (2005). A respirometric method for characterising the organic composition and biodegradation kinetics and the temperature influence on the biodegradation kinetics, for a mixture of sludge and bulking agent to be co-composted. Bioresour. Tech., 96 (2), 169-180 (12 pages).

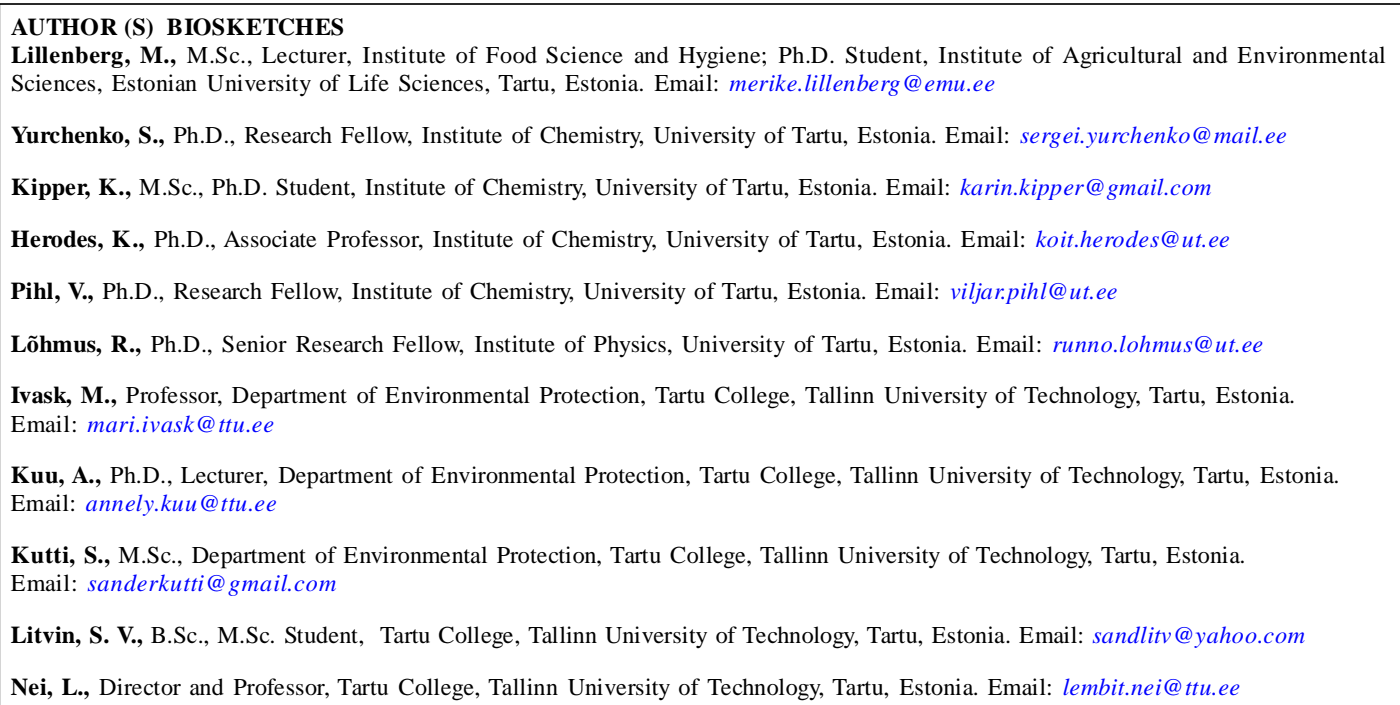

